\title{
Head teachers' Supervision of Curriculum Implementation: Implications on Provision of Quality Secondary Education in Kenya
}

\author{
Jennipher Atieno Awiti \\ School of Education, Jaramogi Oginga Odinga \\ University of Science and Technology \\ Henry Onderi \\ School of Education, Jaramogi Oginga Odinga \\ University of Science and Technology \\ Pamela Raburu \\ School of Education, Jaramogi Oginga Odinga \\ University of Science and Technology
}

\begin{abstract}
This study sought to find out how the head teachers' supervision of curriculum implementation influences provision of quality education in Kisumu East Sub-County Secondary schools, Kenya. The study population consisted of 13 public and 4 private secondary schools in Kisumu East Sub-County. The total population of the study was 1114. Out of these 924 were Form Four candidates, 174 teachers and 17 head teachers. The study used a sample size of 382 consisting of 308 Form Four candidates, 58 teachers selected using simple random sampling. A total of 16 head teachers were selected using purposive sampling technique. The instrument validity was ascertained by use of a four-point scale rating by experienced colleagues to ascertain the relevance of the questions while instrument reliability was ascertained using Split-Half Technique. Piloting was done in 4 schools in the neighboring Kisumu Central SubCounty to ascertain Face validity of the instruments. The research design employed in the study was descriptive survey. Questionnaires, interviews and document analysis were used to obtain data. Quantitative data analysis was done using descriptive and inferential statistics with the aid of SPSS version 21 and co-relational techniques. Qualitative data from interviews were analyzed using Thematic Analysis. The findings of the study indicated that there was a strong relationship between head teacher supervision, curriculum implementation and provision of quality education in Kisumu East Sub-County. Challenges faced by head teachers included teacher and student truancy, teacher resistance to supervision exercise, financial constraints hampering quality education provision, interschool transfers and high student dropout rate among others. The study recommended that the head teachers, as internal Quality Assurance Officers at the school level should attend supervision training sessions offered by Kenya Educational Management Institute.
\end{abstract}

Key words: Instructional Supervision, Curriculum Implementation, Quality education provision

\section{INTRODUCTION}

Supervision has been a neglected area of educational management for a long time (UNESCO, 2007 Module 2). One of the main roles of any school is to monitor the quality of education (UNESCO, 2007 Module 8). According to UNESCO (2009) in Paris, Secondary education in many 
countries is seen as ineffective, of poor quality and ill-adapted to contemporary social and economic needs. Teachers are poorly trained and the head teachers' teams lack training suited to the growing diversity and complexity of the tasks facing them (UNESCO, 2009).

In India, Sindhi (2013) writing on 'Does quality assurance in school education ensure transparency and accountability?' suggested that if school authorities adopt a proper quality assurance mechanism for their schools and monitor quality continuously with respect to different identified indicators and appropriate actions, such an approach would help the management and the teachers to become aware of their responsibilities with regard to establishing quality in their management and teaching functions.

In Nigeria, Sabitu and Ayandola (2012) noted that instructional supervision occupies a unique place in the entire education system so becoming extremely necessary to give it prominent attention. However, according to Utake (2012) there is a tendency for some modern school head teachers to shy away from supervision of instruction and they rather occupy themselves with inspecting school building projects, soliciting for funds from Parents Teachers Associations (PTA) and the public, attending to visitors and other less necessary administrative chores (Adebanjo, 2009).

The Government of Kenya noted in its Master plan of education and training (1997-2010) that the majority of schools fall short of providing for the learning needs of their students leading to poor academic performance (Mumo, Kadenyi and Kiboss, 2014). In agreement with this, Sindhi (2013) in India and Gathara (2010) in Kenya wrote that education has become a competitive human enterprise in the 21st Century and should be accorded high priority. As President Uhuru Kenyatta, Kenya noted, investment in Education for the youth is set to transform the country's economy by 2030 (Oduor, 2014). The President further noted that with increased access to learning, many young people would benefit from acquiring skills for entering gainful employment or business.

The reason for emphasizing on quality education is to give learning a meaning. In 2014, the KCSE examinations results indicated that Kisumu East Sub-County attained bottom position in Kisumu County with only 5 candidates managing a mean score of B+ and 22 with B plain. (Kisumu County Examinations Analysis Document, 2014). The latest Joint Evaluation Test (JET, 2015) showed below average scores of 3.4636 (Republic of Kenya, MoEST Kisumu East SubCounty 2015 Results Analysis). According to UNESCO (2009), if Supervision is enhanced then the teachers' job performance is monitored enabling timely corrective measures to be implemented to ensure improvement of teacher competencies and general professional growth.

\section{Literature Review}

According to Darling-Hammond (1997), the highest quality teachers are those who are most capable of helping their students to learn and have deep mastery of their subject matter and pedagogy This affects retention and educational quality since student achievement, especially beyond the basic skills, depends largely on teachers' command of subject matter and their ability to use that knowledge to help students learn (Mullens, Murnane and Willet 1996).

In Pennsylvania, Farley (2010) carried out a study on instructional supervision whose aim was to describe performance criteria, supervisory practices, and the impact these practices had on instruction in three cyber-schools enrolling full-time students. The findings were that 
performance criteria were similar for both traditional and online teachers in sampled schools. However, the study by Farley (2010) Pennsylvania has not fully developed clear methods of curriculum supervision as opposed to this current study that looked at well established head teachers' supervisory practices and how they influence quality education provision in the SubCounty. .

Similarly, in Uganda, Nzabonimpa-Buregya (2013) carried out a study on influence of secondary school head teachers' general and instructional supervisory practices on teacher work performance. The findings of this study indicated that limited general and instructional supervision was commonplace in secondary schools in Uganda. However, the current study concentrated on only one aspect of supervision, Instructional supervision, for a more intense understanding of supervisory practices.

In the same way in West Africa, Frempong (2011) conducted a study in Cape Coast on factors contributing to poor performance of students in the basic education certificate examination in selected public junior high schools in Effutu Municipality. The findings were that contributions to poor academic performance of students included inadequate teaching and learning materials, inability to complete the syllabus among other factors. However, the study by Frempong (2011) described above did not show how head teachers get involved in supervising implementation of curriculum programs, a gap which the current study sealed.

In relation to the above studies, in Kenya, Muriithi (2014) carried out a study to investigate the influence of head teachers' instructional supervision strategies on curriculum implementation in public schools in Imenti South district. The findings were that internal instructional supervision helped teachers to improve in assessment and evaluation, which further influenced curriculum implementation. The study by Muriithi (2014) however concentrated on the cognitive aspect of the curriculum implementation and neglected the quality aspect of innovation and ability to make correct decisions for personal and social gains, which this study sought to find out in Kisumu East Sub-County Secondary schools.

\section{RESEARCH METHODOLOGY}

The study adopted a mixed design which is a research design in which the researcher collects and analyzes data, integrates the findings, and draws inferences using both qualitative and quantitative approaches in a single study (James and Busher, 2009). It adopted both techniques because the combination makes it possible to arrive at a richer and more complete description covering fairly all aspects of the phenomena under investigation.

The target population was focused on 17 secondary schools in Kisumu East Sub County, with a total target population of 924 candidates, 17 head teachers and 174 trained teachers. The number of students and teachers were arrived at according to Mugenda and Mugenda (2006) and Bragg (2011), who asserted that a third (33\%) of a population is an adequate sample size for a survey study. Therefore, out of 924, 308 candidates were selected and 58 teachers selected from 174 . Out of 17 head teachers, 16 head teachers were sampled in the study using purposive sampling technique since one school was new and did not have candidate classes.

Questionnaires, Interview schedules and document analysis were used for data collection in the study. According to Orodho (2012), a questionnaire is used to obtain facts and opinions about a phenomenon from people who are informed on a particular issue. In this study, questionnaires were used to collect data from both teachers and students. Interview schedule 
was used to collect information from head teachers and documentary analysis used in order to support the viewpoint or argument of respondents (Mugenda and Mugenda, 2006).

Questionnaires were self-administered so that where issues were not clear to the respondents, they sought clarification, and also, to recover all the questionnaires that were given out. Interviews were conducted in places, like the head teachers' offices, that were convenient to the individual respondents to avoid interruptions from other people.

The current study used both qualitative and quantitative methods for data analysis. Quantitative data was analyzed using both descriptive and inferential statistics with the aid of Statistical Package for Social Sciences version 21. The descriptive statistics was used to describe and summarize the data in form of tables, frequencies and percentages (Saunders, 2012). The percentages and frequencies were used because they easily communicate the research findings to majority of readers (Musungu and Nasongo, 2008).

In the current study, thematic data analysis was used to analyze qualitative data. Thematic analysis is a form of analysis in qualitative research which emphasizes pinpoints, examines, and records data in patterns or themes within the data (Braun and Clarke, 2006). Data were transcribed, retaining the original and verbatim quotes of the participants while re-reading and noting the initial ideas, as was in Raburu (2015).

\section{FINDINGS, INTERPRETATION AND DISCUSSION}

To determine how the head teachers' supervision of curriculum implementation influences provision of quality education in secondary schools in Kisumu East Sub-County, the researcher developed a questionnaire to find the opinions of teachers and students concerning the issue. This was done using Likert-scaled item type questions, in which the respondents chose from a 5-point score; strongly agree (SA), agree (A), neutral (N), disagree (D) and strongly disagree (SD). From the respondents' responses, the researcher computed percentage frequencies as shown in Tables 1 and 2.

Table 1: Students Responses on Supervision of Curriculum Implementation ( $N=240)$

\begin{tabular}{|c|c|c|c|c|c|}
\hline Item & $\begin{array}{l}\text { Strongly } \\
\text { agree }\end{array}$ & Agree & Neutral & Disagree & $\begin{array}{l}\text { Strongly } \\
\text { disagree }\end{array}$ \\
\hline $\begin{array}{l}\text { The principal always joins the class when } \\
\text { another teacher is teaching }\end{array}$ & $(6) 2.5$ & $(25) 10.4$ & $(35) 14.6$ & $(28) 11.7$ & $(146) 60.8$ \\
\hline $\begin{array}{l}\text { Syllabus coverage is ensured through regular } \\
\text { class attendance by the teachers and students. }\end{array}$ & $(83) 34.6$ & (157)65.4 & $(0) 0.0$ & $(0) 0.0$ & $(0) 0.0$ \\
\hline Teachers give well researched work & $(100) 41.7$ & $(111) 46.3$ & $(0) 0.0$ & (29)12.1 & $(0) 0.0$ \\
\hline Syllabus is completed in good time & (12) 5.0 & $(143) 59.6$ & (56)23.3 & $(0) 0.0$ & (29)12.1 \\
\hline $\begin{array}{l}\text { Teachers are always adequately prepared for } \\
\text { their lessons. }\end{array}$ & $(108) 45.0$ & (126)52.5 & (6) 2.5 & (0) 0.0 & (0)0.0 \\
\hline $\begin{array}{l}\text { Supervision of instruction is necessary for } \\
\text { students to do well. }\end{array}$ & $(136) 56.7$ & (6)2.5 & $(86) 35.8$ & $(0) 0.0$ & (12)5.0 \\
\hline
\end{tabular}

\section{Source: Survey data (2015)}

It is evident from Table 1 that a significant majority of students (146) $60.8 \%$ strongly disagreed that the principal always joins the class when another teacher is teaching. A negligible proportion (6) 2.5\% strongly agreed that this was the case. A moderately significant majority (83)34.6\% strongly agreed that syllabus coverage is ensured through regular class attendance by the teachers and students while a greater majority (157)65.4\% just agreed that syllabus coverage is ensured through regular class attendance. 
On the question of whether teachers gave well researched work, $(100) 41.7 \%$ of the students highly agreed and (111)46.3\% just agreed that the case was true. A small majority, (29) 12.1\% disagreed that this was true. This means that to some extent, teachers did poorly researched work, compromising quality of education provision in the Sub-County. It was surprising that only (12)5.0\% highly agreed that the syllabus was completed in time (143)59.6\% just agreed and (29) $12.1 \%$ strongly disagreed that the syllabus was completed in good time. This finding was a strong indication that quality of education in the Sub-County was compromised and students sent to the National examinations rooms when not fully prepared.

Less than half $(108) 45.0 \%$ of the students highly agreed that their teachers are always adequately prepared for their lessons. More than half (126)52.5\% just agreed and (6)2.5\% strongly disagreed that this was true. Therefore it is possible to conclude that some teachers did not prepare for their lessons well.

On whether supervision of instruction was necessary for students to do well, more than half of the students (136)56.7\% highly agreed that this was true. However a moderate majority of the students (86)35.8\% were neutral, (6)2.5\% just agreed and a small group of (12)5.0\% strongly disagreed that supervision is necessary for students to perform well. This shows that a significant majority wanted supervision to take place as they (students) desired to do better and prepare for the challenges outside school.

Table 2: Teachers Responses on Supervision of Curriculum Implementation ( $=45)$

\begin{tabular}{|c|c|c|c|c|c|}
\hline Item & $\begin{array}{l}\text { Strongly } \\
\text { agree }\end{array}$ & Agree & Neutral & Disagree & $\begin{array}{l}\text { Strongly } \\
\text { disagree }\end{array}$ \\
\hline $\begin{array}{l}\text { Head teacher visits the classroom to ensure } \\
\text { teacher content delivery is in line with } \\
\text { recommended syllabus. }\end{array}$ & $(0) 0.0$ & $(45) 100.0$ & $(0) 0.0$ & $(0) 0.0$ & $(0) 0.0$ \\
\hline $\begin{array}{l}\text { Head teacher evaluates teacher to improve } \\
\text { instructional practices }\end{array}$ & $(0) 0.0$ & $(15) 33.3$ & $(30) 66.7$ & $(0) 0.0$ & $(0) 0.0$ \\
\hline $\begin{array}{l}\text { Furnishes teachers with useful professional } \\
\text { material and resources }\end{array}$ & $(0) 0.0$ & $(30) 66.7$ & $(0) 0.0$ & $(15) 33.3$ & $(0) 0.0$ \\
\hline $\begin{array}{l}\text { Head teachers are undertaking internal } \\
\text { supervision of curriculum. }\end{array}$ & $(0) 0.0$ & $(30) 66.7$ & $(15) 33.3$ & $(0) 0.0$ & $(0) 0.0$ \\
\hline $\begin{array}{l}\text { The time allotted for curriculum instruction is } \\
\text { adequate. }\end{array}$ & $(0) 0.0$ & $(15) 33.3$ & $(0) 0.0$ & $(30) 66.7$ & $(0) 0.0$ \\
\hline $\begin{array}{l}\text { Head teachers go round to observe teachers in the } \\
\text { classroom. }\end{array}$ & $(0) 0.0$ & (0)0.0 & $(15) 33.3$ & $(30) 66.7$ & (0) 0.0 \\
\hline $\begin{array}{l}\text { Teachers are committed to proper use of } \\
\text { instructional time }\end{array}$ & $(0) 0.0$ & $(30) 66.7$ & $(15) 33.3$ & $(0) 0.0$ & $(0) 0.0$ \\
\hline $\begin{array}{l}\text { Head teachers visit classroom to oversee how } \\
\text { teachers organize group work }\end{array}$ & $(0) 0.0$ & $(0) 0.0$ & $(30) 66.7$ & $(15) 33.3$ & $(0) 0.0$ \\
\hline Head teachers supervise effectively as expected. & $(0) 0.0$ & $(30) 66.7$ & $(15) 33.3$ & $(0) 0.0$ & (0)0.0 \\
\hline $\begin{array}{l}\text { Head teachers are not bold to point out the } \\
\text { teachers' mistakes to them. }\end{array}$ & $(0) 0.0$ & (30) 66.7 & $(0) 0.0$ & (0)0.0 & (15)33.3 \\
\hline $\begin{array}{l}\text { Head teachers discriminate and are not fair and } \\
\text { firm }\end{array}$ & $(0) 0.0$ & (15)33.3 & (15)33.3 & $(0) 0.0$ & (15) 0.0 \\
\hline $\begin{array}{l}\text { Head teachers provide a time table for smooth } \\
\text { coordination and teaching. }\end{array}$ & (0) 0.00 & $45(100.0)$ & $(0) 0.0$ & $(0) 0.0$ & $(0) 0.0$ \\
\hline $\begin{array}{l}\text { Head teachers have knowledge and skills of } \\
\text { supervision }\end{array}$ & (15)33.3 & (15)33.3 & $(0) 0.0$ & $(0) 0.0$ & (15)33.3 \\
\hline $\begin{array}{l}\text { Head teachers are sufficiently trained in } \\
\text { supervision. }\end{array}$ & (15)33.3 & (15)33.3 & (15)33.3 & $(0) 0.0$ & $(0) 0.0$ \\
\hline $\begin{array}{l}\text { Students have adequate learning and teaching } \\
\text { materials. }\end{array}$ & (0)66.7 & $(30) 66.7$ & $(0) 0.0$ & $(15) 33.3$ & $(0) 0.0$ \\
\hline
\end{tabular}


The finding of the study (Table 2) shows that supervision of curriculum implementation in the secondary schools in Kisumu East Sub-County by the head teacher is real. This finding was similar to that of Muriithi (2014) in Imenti South that supervision by the head teachers was good and that it was done daily. From the findings (30) $66.7 \%$ of teachers confirmed that the head teachers were undertaking internal supervision of curriculum as required. Only a small number (15) 33.3\% of the teachers said their head teachers were not adequately and effectively supervising the implementation of the curriculum.

The current study also found out that the head teachers evaluate teachers to improve instructional practices, as was observed by a third of the teachers who took part in the study. However, a significant proportion (30) $66.7 \%$ of teacher respondents were undecided on whether head teachers really evaluate the staff to improve instructional practices or there were other motives behind their actions.

The analysis of the teacher responses in the current study revealed that third $15(33 \%)$ of the teachers doubted whether the head teachers were sufficiently trained in supervision of curriculum implementation and had the right skills and knowledge to do that. Another study by Muriithi (2014) carried out a study in Imenti South District, Kenya, whose purpose was to investigate the influence of head teachers' instructional supervision strategies on curriculum implementation in public schools found out that internal instructional supervision helped teachers to improve in assessment and evaluation which further influenced curriculum implementation.

Only (15)33.3\% of the teachers in the current study agreed that the head teacher possessed the relevant skills and experience to supervise the implementation of curriculum, another (15)33.3\% of the teachers negated the statement that the head teachers had relevant skills to supervise curriculum implementation and the last (15)33.3\% of teachers declined to divulge their opinion on the issue of the head teachers being qualified or not. Among the teachers who believed that the head teachers had the required training and experience to supervise teachers on curriculum implementation. Thirty (30) $66.7 \%$ of them said that the head teachers supervise curriculum implementation effectively as expected of them.

Involvement of students in decision making was noted as one of the findings of the study; about a fifth (50)20.8\% of students strongly agreed, (99)41\% of them just agreed and only (34) $14.2 \%$ of the students disagreed that decision making among the students were encouraged by selection of students as peer counselors and as members of student councils. Similar findings were made by Abebe (2015) in a study of School Management and DecisionMaking in Ethiopian Government Schools that, participation of students in decision-making has played a role in the improved and expanded school-based management. At the same time, in the current study, student innovativeness (a quality education indicator) was encouraged in the schools through science congress, drama, music, and comic entertainments. In the same way, Nzambi (2012) whose study on role of the head teacher in instructional supervision as perceived by teachers in secondary schools in Kitui County, Kenya found that head teachers in Kitui encouraged new ideas, and supported creativity, innovation and practice of new skills. Nearly two thirds (157)65.4\% strongly agreed and (58)24.2\% just agreed that participation and involvement of students in these activities build innovativeness among the students. 
Thirty (30) $66.7 \%$ of the teachers confirmed that the head teachers were committed to proper use of instructional time and to do this head teacher ensures that teachers' time allotted for curriculum instruction was adequate. This was confirmed by a third of the teachers who took part in the study, notwithstanding (30) 66.7\% of the students having said that the head teacher did not go any extra mile to provide the teachers with adequate instruction time. In another study by Adeyemo (2012) Lagos, Nigeria on effectiveness of Laboratory equipment supplies and student performance, the research findings were that adequate supply of physics teachers and provision of laboratory facilities determine to a great extent, students' academic performance in physics. In a study by Olatunde and Otieno-Omondi on learning resources and performance of Mathematics in Bondo district it was found that classroom/laboratories and stationeries/teaching aids are significant in ensuring education quality. Similar findings were made by Yadar (2007) and, a report by UNESCO (2008) that teaching/learning materials such as textbooks, class rooms, teaching aids (chalk, board, ruler and protractor) stationeries and laboratories affect academic performance of the learners.

On the part of the syllabus coverage and content delivery, 15 (33.3\%) of the teachers believed that the students did not have adequate learning and teaching materials. Nevertheless, all the students believed [strongly agree :( 83) 34.6\%; agree :( 157) 65.4\%] that syllabus coverage was ensured through regular class attendance from both the teachers and students. Although, (56) $23.3 \%$ of the students remained non-committal, nearly two thirds of the students agreed that syllabus was completed in good time for the various classes and subjects. It was also noted that most teachers in Kisumu East Sub-County give students well researched work, as was observed by the majority [strongly agree: (100) 41.7\%; agree:(111) 46.3\%]of the students themselves, with only (29) $12.1 \%$ of the students not agreeing. In fact a further (108) $45.0 \%$ of students strongly agreed that teachers were always adequately prepared for their lessons, (126) $52.5 \%$ also supported the statement and only the remaining negligible (6) $2.5 \%$ of the students indicated that teachers were not always adequately prepared. In the same way Frempong (2011) studying in Cape Coast on contributions to poor academic performance of students found that inadequate teaching and learning materials, teacher and student absenteeism and lateness, inability to complete the syllabus, were some of the major factors.

However, it emerged from the findings of the study that some head teachers' failure to effectively supervise curriculum implementation was founded on the fact that they favored some members of staff and discriminated against others. This was confirmed by the slightly more than half (30) $66.7 \%$ of the teacher respondents and agreed that the head teachers were discriminating and were not fair and firm on professional matters. In fact, a significant proportion (15) $33.3 \%$ of the teacher respondents who participated in the study also added that the head teachers were not bold enough to point out the teachers' mistakes to them.

This finding was in agreement with that of Olatunde and Otieno-Omondi (2010) in a study on performance of Mathematics in Bondo Sub-County that supervision that promotes instructional improvement is the primary responsibility of school leaders.

\section{QUALITATIVE RESULTS}

The current study adopted thematic analysis for qualitative data. The themes that emerged from interview sessions with head teachers in Kisumu East Sub-County were: decision making, innovativeness, supervision of curriculum implementation and issues on curriculum supervision tools. The emerging themes are discussed below. 
Decision Making is regarded as the cognition process resulting in the selection of a belief or a course of action among several alternative possibilities or, the thought process of selecting a logical choice from the available options, (McClafferty, 2015). The current study sought to find out if schools in Kisumu East Sub-County enabled their students to develop this ability. From the interview with head teachers it emerged that one way of encouraging students to make decisions is to allow them to choose their own Student Council. The current method of selecting what was originally 'the prefect body' changed to a system where students organize themselves in some sort of campaign rallies where other students select the most convincing candidate to represent them in given positions in the school.

'In this manner, they are encouraged to develop the skill of making their own decisions on who is to be included in the Student Council...such leaders can be 'removed from further leadership' if they do not measure up to the expectations of the student body who elected them' (Head Teacher 6).

This means that students in Kenya, and in Kisumu East in particular are allowed to make informed choices from their own internal interactions. This enables them to choose their own leaders, whom in their view give them the kind of leadership they expect in the school. De Grauwe and Lugaz (2011) in a study of Kenya, Uganda and Lesotho wrote on strengthening local actors: the pathway to decentralization, that greater decentralization of educational decision-making is becoming the common aspiration of many developing countries.

A head teacher explained that:

'..once the student council has been chosen, any adjustment to the school program must be done in consultation with the students. Students must have a meeting to forward their ideas to the administration' Head Teacher 4.

In agreement with this finding, Luck (2011) in a study 'School principals' effectiveness and leadership quality in educational management, found out that in some Asian countries like Malaysia, School management has improved because it involves students and communities in the school decision-making.

\section{Head Teachers on Innovativeness.}

Innovation may well be the most important educational issue of the day according to Moyle, (2010) which means the skill and imagination to create new things. Innovativeness refers to cleverness, creativity, ingenuity, inventiveness, originality. When asked if students were encouraged to be innovative, a few head teachers answered that students were encouraged to be innovative by creating talent days where best talents were awarded while all head teachers agreed that students are encouraged to present talent items during school occasions like parents' day, prize-giving days or such other related school functions. One of the head teachers retorted:

'One of the dimensions of the school innovation issue pertains to the capabilities required by young people to have a successful life and so contribute to economic, social and individual well being, and also to align the nature and structure of school life with the contemporary culture. For this reason we must ensure that the type of education offered gets the best in the learners through creating talent days which are awarded 
immediately and on school academic days in which their parents are present to boost their morale..' (Head Teacher 11).

This means that the schools in Kisumu East Sub-county are interested in giving their students space to be creative and develop their talents. However majority of the head teachers said innovativeness was encouraged through the Ministry of Education guidelines concerning cocurricular activities, like ball games, athletics, science congress, drama and music festivals. One of the head teachers reported:

'The Ministry of Education has pre-prepared Term dates which guide the school activities during different seasons the whole year, like athletics season in First term and Music and Drama season in Second Term..we have no choice but to train the young talents during the given dates and school calendar'. (Head Teacher 10).

This means that the Ministry of Education is very instrumental in ensuring that the young talents are developed in the country. The schools are responsible for the implementation of the same.

\section{Supervision of Curriculum Implementation}

Due to lack of time to undertake supervisory duties it emerged that many head teachers used Management By Walking Around, (MBWA) method to supervise their teachers. It was found that some head teachers make timetables of sorts where class attendance can be noted by class secretaries signing in when teachers have taught their classes. According to Nancy Austine (2013) and Kelly (2015) and expounding on Tom Peter's (1982) most successful book, 'In search of Excellence', Management by Walking Around refers to managers spending some part of their time listening to problems and ideas of their staff, while wandering around an office or plant. The idea of this practice is to listen and respond to ideas or problems voiced and take effective action about them. A head teacher cited:

'When we walk around the classes especially the early morning lessons, teachers are motivated to attend to their classes in time, students are motivated to attend those lessons in time and a cordial relationship is developed between the teacher and the head teacher. Other teachers who come to school late, missing their first lessons are motivated to come earlier in to attend their next lessons, some, to be in 'good books' with the head teacher but others, out of fear of being asked to explain' (Head Teacher 7)

This finding was in line with what Tom Peters (1982) stipulated in the book 'Essential Skills for an excellent career' that Management By Wandering About helps in accessibility to staff who then gain from the manager's experience, approachability, trust, business knowledge, accountability morale and productivity (Kelly, 2015).

In contrast to Head Teacher 7, another head teacher explained why he does not use the MBWA approach to supervision:

'We have a mechanism by which we can monitor the activities even from the office. All class representatives, (formerly class monitors have an empty outline of the time table where they insert the name of each teacher and subject, to mark 'taught' or 'missed' accordingly. They also indicate the time the teachers enter and leave the classes so 
that we can know the time wasters and invite them for further follow up discussions.' (Head Teacher 12)

For this reason, head teachers are in control even from the office without having to hang around classes and create fear and despondency among the teachers and students. Learning still goes on smoothly yet the head teacher is in touch with all that goes on in the classes.

\section{The Head Teacher and Tools for Curriculum Supervision}

It was established, from the head teachers' interview, particularly from the private schools, did not have supervisory tools to use in Curriculum implementation monitoring. Findings from a study by Nzabonimpa-Buregya (2013) in Uganda also indicated that head teachers, to a great extent in private secondary schools did not carry out instructional supervision although they did some informal classroom visits.

'we design our own supervisory tools within the school. We do not have any prescribed guideline from the Ministry of Education to use for monitoring Curriculum Implementation' (Head Teacher10).

Similar findings were made in Ethiopia in a study by Abebe (2014) who found that teachers lacked awareness and orientation on the significance of school-based supervisory activities, lack of supervision manuals in schools and shortage of allocated budget for supervisory activities. Another head teacher in one private school confessed that there were no supervisory tools in the school.

'We do not have any supervisory documents in the school. For supervision, the head teacher ensures that all classes are attended and all teachers must comply' (Head Teacher 11.

If head teachers carried out their supervisory roles well, there was bound to be remarkable efficiency in the work carried out by subordinates. However, some head teachers, particularly from the higher achieving schools said,

'policy guidelines are available for supervision like the Education Act, TSC Act, Basic Education Act, Procurement Act and the like..these are the guidelines from which we extract our own, according to our own school environment' (Head Teacher 2).

Lack of visitation from the Quality assurance Officers is an indication that head teachers did not receive advisory services which they could expect from the officers, especially on supervisory methods of curriculum implementation. This finding was similar to those of Mobegi et.al. (2010), who found that quality assurance officers did not visit schools in Gucha district, making head teachers unable to receive correct advisory services on Curriculum implementation.

\section{CONCLUDING REMARKS}

The study concludes that actual supervision of curriculum implementation is weak in Kisumu East Sub-county. This could explain the low scores by students in KCSE exams with only a few schools able to post high scores. It is important for the quality assurance officers from the Ministry of Education to regularize their visits to the schools in order for curriculum implementation supervision to be further strengthened. The study concluded that there is a 
Awiti, J. A., Onderi, H., \& Raburu, P. (2016). Head Teachers' Supervision of Curriculum Implementation: Implications on Provision of Quality Secondary Education in Kenya. Advances in Social Sciences Research Journal, 3(1) 116-128.

strong positive correlation between head teachers' supervision of curriculum implementation and provision of quality education in Kisumu East Sub-County.

\section{References}

Abebe, W. (2012). A working paper on School Management and Decision-Making in Ethiopian Government schools: Evidence from the young lives: Qualitative school survey. Young lives, an international study of childhood poverty. www.younglives.org.uk

Adeyemo, S. A. (2012). Influence of Teacher supply and the provision of Laboratory Facilities on student achievement in Physics. European Journal of Educational Studies 4(3), 2012, Ozean Publications.

Bertalanffy, V.L. (1950). An Outline of General Systems Theory. British Journal for the philosophy of Science. Vol. 1 No. 2.

Burnard, P., Gill, P., Stewart, K., Treasure, E. \& Chandwick, B. (2015). Analysing

and Presenting Qualitative Data. British Dental Journal Current Issue. RSS Feed Publications. www.nature.com/bdj/journal/v204.htm. Published Online.

Darling-Hammond, L. (1997). Doing What Matters most: Investing in Quality teaching.

De Grauwe, A. \& Lugaz, C. (2011). Strengthening Local Actors: The path to Decentralizing Education; Kenya, Uganda and Lesotho. Paris International Institute for Educational Planning and UNESCO

Farley, G.C. (2010). Instructional supervision: A descriptive study focusing on the observation and evaluation of teachers in Cyberschools. University of Pennsylvania. ERIC Web site:http://www.proquest.com/enUs/products/desertations/individuals.shtml.

Frempong, E. (2011). Factors contributing to poor performance of students in the basic education certificate examination in selected public junior high schools in Effutu Municipality, University of Winneba.

Glanz, J., College, W. Shulman, V., Sullivan, S. (2007). Impact of Instructional Supervision on Student achievement: Can we make the connection? A paper presented at the annual conference of the American Educational Research Association (AERA), Chicago.

Grauwe, A. (2007). Transforming School Supervision in to a tool for Quality Improvement. International Review of Education, 53, 709-714.

James, N. \& Busher, H. (2009). Qualitative Data Analysis. www.sagepub.com/schuttlsw7e pp.34-37

Kisumu County Documents (2015). https://en.m CC BY-SA 3.0

Kisumu County (2014). Examinations Results Analysis. Examinations department 2014.

Kisumu East Sub-County Education office documents (2015). Official schools

Returns. Kisumu East Sub County.[

Kothari, C.R. (2011). Research Methodology, Methods and Techniques. New Age International Publishers, New Delhi.

Likert, R. (1931). A Technique for the measurement of attitudes. Archives of Psychology. New York: Columbia University Press.

Luck, T.L. (2011). School Principals' Effectiveness and Leadership quality in educational management, Johor: Mara University of Technology

McClafferty, (2015). 5 Simple Ways to Improve Decision-making. www.forbes.com/sites.

Ministry of Education \& Ministry of Higher Education, Science and Technology. Sessional Paper No...of 2012. A policy Framework for Education and Training: Reforming Education in Kenya. Task Force Report. (2012).

Republic of Kenya.

Minisrty of Education Statistics (2015). Education For All 2015: the 2015 National Review - Unesdoc efa 2015 review@unesco.co.org.

Mobegi, F.O., Ondigi, A.B. \& Odhiambo P.O. (2010). Secondary School Head teachers' Quality Assurance Strategies and Challenges in Gucha District, Kenya. Educational Research and Reviews. Vol 5(7) pp. 408-414.

http//www.academicjournals.org/ERRZ ISSN 1990-3839 Academic Journals. 
Mugenda, A. \& Mugenda, O. (2006). Research Methodology: Qualitative and Quantitative Approach. ACTS Press, Nairobi.

Mumo, R.M., Kadenyi, M.M. \& Kiboss, J.K. (2014). Instructional Supervisory Skills used for Academic Performance by Head Teachers in (KCSE) in Public Schools in Machakos. International Journal of Education and Research. Vol. 2 No. 10, Oct. 2014

Muriithi, M.M. (2014). Influence of head teachers' Instructional Supervision Strategies on Curriculum Implementation in Public Primary schools in Imenti South District, Kenya. Compiled and produced by Kenya Information Preservation Society.

Musungu, L.L.\& Nasongo, J.W. (2008). The Head-teachers' Instructional role in academic achievement in Secondary Schools in Vihiga District, Kenya. Educational research and Review Vol. 3 (10) pp 316-323 ISSN 19903839.

Nyanza Province (2013). KCSE Examinations Results Analysis. Examinations department 2013.

Nzabonimpa-Buregeya, J. (2013). Influence of Head Teachers' General and Instructional Supervisory Practices on Teachers' Work Performance in Secondary Schools in Entebbe Municipality, Wakiso District, Uganda. Makerere University eric.ed.gov/ED527043pdf

Nzambi, N.P. (2012). Role of the Head Teachers in Instructional Supervision as perceived by Teachers in Secondary Schools in Kitui District, Kitui County, Kenya. Kenyatta University. Irlibrary.ku.ac.ke/bitstream/handle/12345678/7277.

Oduor, A. (2014). TSC Officials Boycott Ministry's Meeting over Clash The Standard Newspaper, March 14th.

Olatunde, Y., and Otieno-Omondi, K. (2010). Teaching-Learning resources and Academic Performance in Mathematics in Secondary Schools in Bondo District. Asian Social Science Vol. 6. No. 12. Dec. 2010. www.ccsenet.org/ass.

Orodho, P. (2012). Techniques of writing Research proposals and reports, Nairobi: Reata Printers.

Peters, T. (1982) In Search Of Excellence. Essential Skills for an Excellent Career. www.mindtools.com/pages/articlenewTMM-72htm.

Raburu, P.A. (2015). Motivation of Women Academics and Balancing Family and Career. Journal of Education and Social Research Vol 5 pg. 359-370.

Republic of Kenya, (2010). Master Plan on Education and Training, 1997-2010. Republic of Kenya 1998.

Republic of Kenya, Ministry of Education, Science and Technology State Department of Education (2015). Kisumu East Sub-County Form Four 2015 Result Analysis. Analyzed by ICT Solutions, Kisumu.

Saunders, M. (2012). Research Methods for Business Students. Pearson Custom Publishing 6th edition

Sindhi, S. (2013). Does Quality Assurance in School Education Ensure Transparency and Accountability? Counter Currents Org

Sullivan, S \& Glanz, J. (2000). Supervision that improves teaching. Thousand Oaks: Crown Press.

The Kenya Institute of Education Order. (2010). Republic of Kenya. Ministry of Education.

UNESCO. (2000). Education for All 2000 Assessment. Dakar: UNESCO.

UNESCO. (2005). Challenges of Implementing Free Primary Education in Kenya: Assessment report, UNESCO, Nairobi Office.

UNESCO. (2007) Module 2. Supervision: A Key Component of a Quality monitoring System Module International Institute for Educational Planning, (IIEP) 7-9 rue Eugene-Delacroix 75116 Paris.

UNESCO. (2008) Module 8. Background Paper Prepared for the Education for All Global Monitoring Report, 2008. 2008/ED/EFE/MRT/P1/12

UNESCO. (2008). Challenges of Implementing Free day secondary education in Kenya: Experiences from Districts, Nairobi, UNESCO.

UNESCO. (2008). EFA Global Monitoring report. Paris. UNESCO.

UNESCO. (2009). The New roles of Secondary school head teachers. UNESCO

Interagency Group on Secondary Education. ED - 2009/WS/57. France. 
Awiti, J. A., Onderi, H., \& Raburu, P. (2016). Head Teachers' Supervision of Curriculum Implementation: Implications on Provision of Quality Secondary Education in Kenya. Advances in Social Sciences Research Journal, 3(1) 116-128.

Utake, M.A. (2012). The nature and purpose of supervision for quality assurance in schools. Research in Education $18,18(1)$.

Voltruba, L. (1988). Development in Water Science. Elsevier Science Publishing Company 52 Vanderbilt Avenue, New York N.Y. 10017.

Yadar. K. (2007). Teaching of Life Sciences. New Delhi. Aumol Publications Ltd. India 